\title{
Managerial Incentives And Changes In Corporate Focus
}

Ronald W. Best (E-mail: rbest@westga.edu), State University of West Georgia Charles W. Hodges (E-mail: chodges@westga.edu), State University of West Georgia Bing-Xuan Lin (E-mail: blin@uri.edu), University of Rhode Island

\begin{abstract}
We examine how Chief Executive Officer (CEO) equity ownership, CEO tenure, and the percentage of options in CEO annual compensation are related to decisions regarding changes in corporate focus. We document that the CEOs whose companies change their level of corporate focus have significant differences from CEOs whose firms do not change focus. However, we find no differences in the characteristics of CEOs who increase their firm's level of diversification and the CEOs who decrease their firm's level of diversification. Firm characteristics, such as size or whether the firm sells at a premium or discount to its peers, are better predictors of changes in corporate focus than CEO characteristics. Overall, we find no evidence that changes in diversification are related to self-serving managers attempting to maximize their own wealth.
\end{abstract}

\section{Introduction}

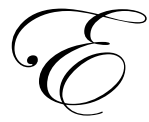

mpirical studies on changes in corporate focus overwhelmingly suggest that focus-decreasing activities (diversification) are value destroying while focus-increasing activities (refocus) enhance firm performance ${ }^{1}$. However, if diversification does not maximize shareholder wealth, it is then perplexing to see waves of merger and acquisition in the 1960s, 1980s, and even in the 1990s. Meanwhile, we have also witnessed an increasing number of firms who decide to spin-off unrelated businesses and focus on their core competencies. To understand the motivations and effects of these focus-changing activities, researchers have examined various hypotheses and theories. They have looked at: (i) efficiency of internal capital markets within a diversified firm (Stein (1997), Scharfstein and Stein (2000), Billett and Mauer (2003) Rajan, Servaes and Zingales (2000)), (ii) increase in debt capacity and reduction in bankruptcy costs (Lewellen (1971), Melnik and Pollatschek (1973)), (iii) wealth transfers between equity holders and bondholders after diversification (Mansi and Reeb (2000)), (iv) the impact of information asymmetry on the value of the diversification discount (Hermalin and Katz (2000)) and (v) the performance of firms with different levels of focus (Lang and Stulz (1994), Comment and Jarrell (1995), Berger and Ofek (1999)).

Some have argued that focus-changing activities especially focus decreasing activities, are caused by selfserving managers trying to maximize their own utility at shareholders' expense. For example, Amihud and Lev (1981) hypothesize that managers choose to engage in conglomerate diversification because they have undiversifiable "employment risk". Shleifer and Vishny (1989) suggest that the reason for managers to build up a diversified firm is to gradually make their employment with the firm irreplaceable. Managers will then be able to extract more perquisites when they become vital to the success of the firm. However, many papers emphasize only the relationship between the level of corporate focus and agency characteristics. They tend to ignore whether or not these agency factors are actually related to the change of focus. For instance, Amihud and Lev (1981) show that managers in diversified firms tend to have higher equity holdings, and Rose and Shepard (1994) suggest that CEOs in diversified firms have a substantial compensation premium. These results may explain why managers will have incentives to maintain the value-destroying diversification in order to secure personal benefits. However, they do not tell us if these agency factors cause firms to change focus in the first place.

1 For example, see Lang and Stulz (1994), Berger and Ofek (1995), Comment and Jarrell (1995), Lins and Servaes (1999), Berger and Ofek (1999), Denis and Thothadri (2000) etc. 
Current research findings present conflicting findings as to whether focus-decreasing activities (diversification) are related to agency conflicts between managers and shareholders. ${ }^{2}$ Denis, Denis and Sarin (1997) find that the equity ownership levels of managers are negatively associated with the number of segments. They interpret this result as being consistent with the hypothesis that self-serving managers attempt to maintain valuedestroying diversification. One question they have not answered in their paper is whether the low equity ownership actually is linked to the firm's decision to diversify in the first place. Additionally, Anderson, et al. (2000) show that diversified firms have very different governance mechanisms, and that these governance mechanisms are used as substitutes for low pay-for-performance sensitivity and CEO ownership. Therefore, equity holdings by managers may not provide a complete explanation for firms that remain diversified.

Most studies, except for Anderson et al. (2000), examine diversification and refocus decisions within separate frameworks. A natural question to ask is whether some common agency factors that are related to changes in focus and if other common agency factors that have opposite effects on diversification and refocus. Anderson et al. provide some descriptive statistics for different ownership and governance characteristics between firms that increase and reduce focus. Based on the differences in mean and median, they provide some explanations as to how these characteristics may be related to focus change. However, they do not test whether these characteristics are related to the probability of a focus change.

Therefore, in this paper we will explore how the agency characteristics of a firm might provide different incentives to the CEO when making decisions to change the level of corporate focus. Specifically, we will look at how the CEO equity ownership, percentage of option-based compensation, and CEO tenure might be related to focus-changing activities. The major contribution of this paper is to test how CEO characteristics are related to a firm's decision to change focus. Furthermore, we will examine both focus-increasing activities (FIAs) and focusdecreasing activities (FDAs) in the same framework. In this way, we can make direct comparisons among firms that increase focus, decrease focus and maintain the focus level.

Overall, we find that decisions to change focus are not influenced by the agency characteristics of the firm's Chief Executive Officer. The effects of agency characteristics on focus change are, at best, secondary to firm characteristics. We find no evidence that focus-decreasing activities are driven by self-serving managers trying to extract personal benefits at shareholders expense. On the contrary, we find some support that CEO equity ownership is negatively related to the likelihood of refocusing. This implies that when CEO equity holdings go up, he/she becomes less diversified and will avoid refocus activities. However, we also find CEOs with very high equity ownership are more likely to have their interests aligned with those of shareholders and therefore employ more focus-increasing activities.

The remainder of the paper is structured as follows. Section II describes the hypotheses and reviews the existing literature. Section III describes the data and presents the empirical results. Finally, section IV contains conclusions.

\section{Hypotheses And Literature Review}

The "agency cost" hypotheses have been formulated as early as Jensen and Meckling (1976) to explain many corporate events. Its application in understanding diversification and refocus decisions also shows great promise. However, the agency conflicts between managers and shareholders can be rather complex because the same incentive contract can bring out very different managerial behaviors depending on one's assumptions. Often the same variable can generate two seemingly opposite predictions. It then becomes an empirical question to determine which hypothesis is likely to be the dominant one in the relationship.

Many of the following hypotheses are direct extensions of results found in other areas of corporate finance. For example, there have been some studies that look at the relationship between the form of compensation and firm value, CEO tenure and firm value, equity ownership and Tobin's $Q$, etc.

\footnotetext{
2 The only evidence we have is that focus-increasing activities (refocus) are not associated with managerial equity ownership. (Denis, Denis and Sarin (1997))
} 
Previous work has looked at the agency relationship between officers, board of directors and shareholders, as well as between the CEO and shareholders. In this paper, we look only at the relationship between the CEO and shareholders, as the CEO should have the highest personal interest and presumably invests the most human capital and effort in the firm. If there is any agency conflict, it should be most apparent when we look at the relationship between CEO and shareholders.

\subsection{CEO Equity Ownership And The Change Of Corporate Focus}

Amihud and Lev (1981) hypothesize that managers have undiversifiable "employment risk", therefore they might have incentives to diversify at the firm level. The "employment risk" comes from the fact that managers have to invest their limited "human capital" within the firm. Furthermore, their future wealth and employment are closely related to the firm's risk exposure. Risk-averse managers will then minimize the probability of financial distress by stabilizing the future income stream through focus decreasing activities. Amihud and Lev measure the "employment risk" with equity ownership and test their hypothesis using 309 firms covering a period during the 1960s. They find a positive relationship between the equity ownership and their measure of diversification, and they interpret this result to be consistent with the hypothesis of risk reduction as a motivation for conglomerate mergers. Under this hypothesis, we would expect CEOs with higher equity ownership to employ more focus-decreasing activities. For the same reason, CEOs with higher equity holdings are less likely to engage in focus-increasing activities, because corporate refocus will increase the "employment risk" of managers.

Denis, Denis, and Sarin (1997) also provide evidence on the agency cost explanation for corporate diversification. Their study of 933 firms selected in 1984 suggests a negative relationship between the level of diversification and managerial equity ownership. They claim their result to be consistent with the hypothesis that self-serving managers have the incentives to extract the personal benefits of corporate diversification (higher pay, reputation...) at shareholders' expenses. Because of low equity ownership, manager's interests are not aligned with those of shareholders. Therefore, a natural extension of above result is to see whether CEOs with lower equity ownership have less incentive to engage in focus increasing activities. Unfortunately, in their paper, they do not find supporting evidence for this hypothesis. They show an insignificant relationship between equity ownership and the probability of refocus. Thus, existing research gives an ambiguous answer to this question. However, the fact remains that if lower equity ownership is the reason for a manager to keep value-destroying diversification in place, we should expect CEO's with higher equity ownership to have more incentives to engage in focus-increasing activities.

The above two studies raise two different hypotheses regarding the relationship between equity ownership and diversification ${ }^{3}$. Both of these papers look at corporate focus level and managerial equity ownership at the same time and describe the relationship between equity ownership and diversification. However, to learn if higher equity ownership is related to a firm's decision to engage in focus decreasing activities, we need to examine the impact of managerial equity ownership prior to change in focus and the incremental change in focus afterwards. Since incentive contracts are awarded to ensure that future managerial decisions are closely aligned with the interests of shareholders, it is a more relevant analysis to examine how compensation contracts at $\mathrm{t}-1$ are related to the decisions of focus change at $t$.

We can also expect a non-linear relationship between equity ownership and the likelihood of focus increasing activities. Higher equity ownership provides CEOs with more incentives to maximize firm value, but it also causes CEOs to worry more about their undiversified portfolio. To avoid "putting all of their eggs in one basket", they will diversify, and to maximize firm value they will refocus. It is difficult to generalize which one of these effects is the dominant force in the decision or whether there is different effect at different levels of equity ownership. Some CEOs may want to protect their "human capital" through diversification at lower or medium levels of ownership and then engage in refocus activities in order to enhance firm value when their holdings become

\footnotetext{
3 These two hypotheses are not necessary contradictory. Denis Denis and Sarin (1997) also show that for very high ownership holdings (greater than $50 \%$ ), there is some indication of a positive relationship between equity ownership and diversification.
} 
significantly large. Other CEOs may engage in value-enhancing refocus at first when they slowly increase their equity holdings, and then decide to engage in diversification if their portfolios become too concentrated ${ }^{4}$.

\subsection{Fraction Of Equity Compensation And The Change Of Corporate Focus}

Mehran (1995) presents a model where the form rather than the level of compensation is what motivates managers to increase firm value. CEO compensation consists of cash compensation and equity compensation. Equity compensation is often awarded in the form of stock options. This has become increasingly popular because stock options not only align the interests between CEOs and shareholders, but also induce risk-averse CEOs to take more risky projects for the firm. CEOs that have their wealth in the form of options will have more incentives to increase firm risk and thus they are more likely to shun the idea of stabilizing cash flows through diversification. Additionally, due to the alignment of interests induced by the awarded option, CEOs have no incentives to engage in wasteful conglomerate M\&A. Under this hypothesis, we should expect a negative (positive) relationship between equity-based compensation and the probability of focus decreasing (increasing) activities.

\subsection{CEO Tenure And Changes In Corporate Focus}

Shleifer and Vishny (1989) suggest that managers build up a diversified firm to gradually make their employment with the firm irreplaceable. They will then be able to extract more perquisites when they become vital to the success of the firm. We would expect such incentives to have the most impact when the CEO tenure is short (the first few years he starts his career in the firm). On the other hand, a CEO with longer tenure is more likely to be successful with his plan in making himself irreplaceable; therefore, he will have less incentive to engage in further diversification. Consistent with this hypothesis, Berry, Bizjak, Lemmon and Naveen (2000) show that diversified firms tend to have CEOs with shorter tenure. Additionally, Chung and Pruitt (1996) suggest that CEOs with longer tenures might increase their "loyalties" to the firms, since their equity holdings are usually higher the longer they stay with the firm. Therefore, we would also expect them to enhance firm value through focus-increasing activities and reduce focus-decreasing activities. The above hypothesis would suggest a negative (positive) relationship between CEO tenure and the probability of focus decreasing (increasing) activities.

On the other hand, we might also expect a positive relationship between CEO tenure and the probability of diversification. Managing a diversified firm usually requires more years of experience and a good understanding of the existing operation. A CEO with a longer tenure in a firm may be more likely to pursue focus-decreasing activities because he is more likely to get it right. For the same reason, CEOs with shorter tenures might avoid focus-decreasing activities before they establish a performance record and make themselves valuable in a diversified firm. Additionally, new CEOs might have the need to signal their abilities to the market. Therefore, they are more likely to devote themselves to promoting the performance of the firms through value increasing refocus programs.

\subsection{Control Variables And Other Considerations}

Other control variables used here include size, leverage, performance, and the level of diversification of the firm in the prior year. Previous research has shown that diversified firms are larger in size, and usually trade at discounts when compared to focused firms. Furthermore, Denis et al. (1997), as well as Berger and Ofek (1999) show that firms that perform poorly in the prior year are likely to undo their "mistakes" and engage in focus increasing activities. Additionally, Berger and Ofek (1999) show that the focus level of the firm prior to a focus change is an important control variable. Firms with low (high) focus levels are more likely to engage in focus increasing (decreasing) activities.

\footnotetext{
4 Some may argue that the diversification effect should be most prominent when CEOs have the highest equity ownership. This is only true if diversification has, on average, no effect on firm value. If diversification, on average, reduces firm value, the benefit of holding a diversified portfolio can be outweighed by the loss in the value of the diversified firm.
} 


\section{Data Description And Empirical Results}

To construct the sample, we obtain firm segment information for the period between 1992 and 1998 from Computstat Industry Segment Tape. Consistent with previous studies (e.g. Berger and Ofek (1995)), we also exclude financial firms (SIC code 6000-6999) and utilities (SIC code 4900-4999) from the sample. For inclusion in the sample, a firm should also have sales greater than 20 million. To ensure data accuracy, we remove the firm from our sample if the computed total segment sales are not within $1 \%$ of the sales reported on the annual Compustat tape. Firm level accounting data such as total assets, revenues etc. are retrieved from the 1999 Compustat Active tape and Research tape. Additionally, the firm should have enough information to compute the measure of excess value using the methodology in Berger and Ofek (1995).

Another major source of data comes from Compustat Exec Comp. It features over 80 different compensation, executive, director, and company related data items from 1992 forward. Companies contained in S\&P 500, 400 MidCap and 600 SmallCap are included in the database with over 30 different measures of company financial performance. Additionally, the Exec Comp database also provides the computed dollar value of awarded options. The CEO compensation variables described here are consistent with previous studies. We report the descriptive statistics for CEO total compensation, CEO equity ownership, and the percentage of option-based compensation, CEO age and CEO tenure. CEO total compensation (in thousands) is computed by adding salary, bonus, other annual compensation, total value of restricted stock granted, total value of stock options granted (using Black-Scholes), long term incentive payouts and all other compensation.

\section{Table 1: A Comparison Of Single Segment (Focused) Firms With Multi-Segment (Diversified) Firms}

Tenure is the number of years the CEO has been in place. Percentage of pay in options is the ratio of the value of the CEO's option value to the total compensation. CEO total compensation is computed by adding salary, bonus, other annual compensation, total value of restricted stock granted, total value of stock options granted (using Black-Scholes), long-term incentive payouts and all other compensation. CEO equity ownership is the percentage of the company's shares owned by the CEO as reported in the proxy statement. Data is from the Exec Comp database for the period 1992-1998.

\begin{tabular}{|c|c|c|c|c|c|c|}
\hline & $\mathbf{N}$ & Mean & Median & Std Dev. & Minimum & Maximum \\
\hline \multicolumn{7}{|c|}{ Descriptive Statistics for the Full Sample: } \\
\hline Total Compensation & 4673 & 2731.68 & 1509.61 & 4593 & 0.001 & 90818.07 \\
\hline$\%$ pay in options & 4673 & 31 & 28 & 28 & 0.00 & 100 \\
\hline Age & 2548 & 56.93 & 57 & 7.91 & 31 & 86 \\
\hline Tenure & 4730 & 7.46 & 5.00 & 7.53 & 0 & 53 \\
\hline Equity ownership & 2357 & 6.02 & 2.3 & 8.87 & 0.01 & 63.2 \\
\hline \multicolumn{7}{|c|}{ Descriptive Statistics for Single Segment (Focused) Firms: } \\
\hline Total Compensation & 3230 & 2520.33 & 1344.34 & 4338 & 0.001 & 90818.07 \\
\hline$\%$ pay in options & 3230 & 32 & 29 & 30 & 0.00 & 100 \\
\hline Age & 1690 & 56.18 & 56 & 8.02 & 31 & 84 \\
\hline Tenure & 3267 & 7.62 & 5 & 7.56 & 0 & 49 \\
\hline Equity ownership & 1797 & 6.23 & 2.50 & 8.95 & 0.01 & 63.20 \\
\hline \multicolumn{7}{|c|}{ Descriptive Statistics for Multi-segment (Diversified) Firms: } \\
\hline Total Compensation & 1443 & $\begin{array}{c}3204.77 * \\
(0.00)^{*}\end{array}$ & $\begin{array}{c}1922.41 * \\
(0.00)^{*}\end{array}$ & 5088 & 2.684 & 77989.59 \\
\hline$\%$ pay in options & 1443 & $\begin{array}{c}30 * * \\
(0.03)^{* *}\end{array}$ & $\begin{array}{c}27 \\
(0.55)\end{array}$ & 25 & 0.00 & 98 \\
\hline Age & 858 & $\begin{array}{l}58.41^{*} \\
(0.00)^{*}\end{array}$ & $\begin{array}{c}59 * \\
(0.00)^{*}\end{array}$ & 7.47 & 37 & 86 \\
\hline Tenure & 1463 & $\begin{array}{c}7.11^{* *} \\
(0.03)^{* *}\end{array}$ & $\begin{array}{c}5.00 * \\
(0.01)^{*}\end{array}$ & 7.47 & 0 & 53 \\
\hline Equity ownership & 560 & $\begin{array}{c}5.35 * * \\
(0.03) * *\end{array}$ & $\begin{array}{c}1.90^{*} \\
(0.00)^{*}\end{array}$ & 8.60 & 0.01 & 53.8 \\
\hline
\end{tabular}

$*, * *$ and $* * *$ represent significance at $1 \%, 5 \%$ and $10 \%$ level when comparing focused and diversified firms 
A comparison of single-segment (focused) firms with multi-segment (diversified) firms is reported in Table 1. Consistent with previous results, the total compensation for CEOs of diversified firms is higher, on average, than that of focused firms. The tests of mean and median are both significant at the $1 \%$ level. CEO equity ownership is the percentage of the company's shares owned by the CEO as reported in the proxy statement. The percentage of option compensation is the ratio of the value of the CEO's options to total compensation. CEO tenure is the number of years he has been the CEO of the firm. We see that CEOs of multi-segments firms have lower equity ownership and older but have lower tenure. The difference in median between multi-segment firms and single-segment firms are overall significant. The above summary statistics are very similar to the sample statistics of related research, such as Rose and Sehepard (1994) and Berry, Bizjak, Lemmon and Naveen (2000).

While Table 1 documents significant firm and CEO differences between diversified and focused firms, Table 1 does not show causality. From Table 1, we cannot determine if the differences in focus cause the differences in firm characteristics, or if the differences in firm characteristics cause the changes in level of focus. In order to study the relationship between agency factors and decisions to change focus, we need to identify firms that increase focus, decrease focus or maintain focus level. We measure changes in corporate focus following the approach in Berger and Ofek (1999). A firm is said to engage in focus increasing activities (FIA) if it reduces its number of segments and increases its Herfindahl Index on sales by more than 0.1. Similarly, a firm is said to engage in focus decreasing activities (FDA) if it increases its segments and decreases its Herfindahl Index by more than 0.1. A firm is defined to be maintaining its level of focus if there is no change in segments and the Herfindahl Index changes by less than 0.1 .

Table 2 reports a comparison of firms who change their focus with firms who do not changes their focus. Note that the classification of focus increasing (FIA), focus decreasing (FDA) and no change in focus is different from the classification of multi-segment and single-segment firms in the previous table. As would be expected the majority of firms in the sample make no change in their focus, while smaller group acts to decrease firm focus, and the smallest group increases firm focus. Using Size to determine the percentages, 90.2\% (2960/3282) kept the same level of focus, $3.8 \%$ (124/3292) increased their focus, and 6.0\% (198/3282) decreased their focus.

The Table 2 results generally support the argument that firms who change their focus have both firm differences and CEO differences from firms that do not change their focus. We see firms that engage in focus increasing activities, on average; have lower excess value compared to firms with no change in focus. The excess value for firms that engage in FDAs is also lower than that for firms that maintain their focus level (The median is 0.04 for firms that decrease their focus level and 0.13 for firms that maintain focus). CEOs for firms that engage in focus change (both FIAs and FDAs) seem to have higher total compensations than CEOs in the firms with no change in focus. For equity ownership, the tests of medians seem to suggest that CEOs for firms that change focus (both increasing focus and decreasing focus) have lower equity ownership positions when compared to firms that do not change focus. Interestingly, firms that change focus seem to have older CEOs than firms that do not change focus. These last two results are consistent with the CEOs of firms who do not change their focus being more risk averse than CEOs of firms who do change focus.

Table 2 also documents differences in firm characteristics in Focus Increasing firms from Focus Decreasing firms. Consistent with the notion that firms refocus to undo past wasteful diversification, we see FIA firms are larger in size when compared to FDA firms and firms that do not change their focus level. We also show that Focus Decreasing firms generally sell at a premium to Focus Increasing firms, which is again consistent with FIA firms refocusing to undo past wasteful diversification while FDA firms have excess value that they will eventually squander in wasteful diversification. Perhaps the most interesting result of the paper is that there is no significant difference in the characteristics of CEOs increase their firm's focus and those CEOs who decrease their firm's focus. The results are consistent with certain types of CEOs having a bias towards change in their company. However, we have no explanation as to why these change oriented CEOs are more likely to diversify their firm, generally a value decreasing action, than to focus their firm, generally a value increasing action. Nor, can we use CEO characteristics to predict which of these CEOs will diversify versus focusing their firm. 


\section{Conclusion}

One major hypothesis for change in corporate focus involves agency conflicts between managers and shareholders. Previous studies have identified relationships between the level of corporate focus and the agency characteristics of a firm, but there has been no direct evidence to link corporate focus changes to agency conflicts. For example, the fact that CEOs in diversified firms have lower equity ownership than CEOs in single segment firms does not mean low equity ownership is associated with a firm's decision to engage in conglomerate diversification. Lower equity ownership in diversified firms can be due, for example, to different corporate governance structures.

The contribution of this paper is to examine how agency conflicts between CEOs and shareholders are linked to a firm's decision to change focus. Specifically, we test how CEO equity ownership, CEO tenure and the percentage of option in CEO compensation may affect the change in corporate focus. Overall, there is little support for the hypothesis that agency conflicts and a firm's decision to diversify are closely related. However, we do find some support that CEO risk aversion may provide an incentive to maintain the level of focus and avoid focusincreasing activities. Our results show some support of the argument that both firm and CEO characteristics are the drivers of changes in firm focus. We also demonstrate that differences in firm characteristics, rather than differences in CEO characteristics, are the better predictors of whether firms are likely to refocus or to diversify.

Corporate restructuring and focus changes are complex decisions, and the agency effects, if any, of such decisions can also be complicated. Since agency conflicts can cause potentially conflicting behavior, on average, we might not identify a dominant force that relates to changes in focus. Although the findings in this paper suggest that "agency conflicts" do not fully explain the probability of a change in corporate focus, we should interpret the results with caution. Future studies should look at cross-sectional differences and examine whether or not firms with different characteristics in capital structure, governance structure, managerial risk-aversion, manager abilities etc. behave differently from each other. Research on this subject can help shareholders properly design the incentive contracts to fit their firm's profile.

\section{Table 2: A Comparison Of Firms With Changes In Focus And Firms With No Change In Focus}

Sample merges Computstat Active Tape, Research Tape, Segment Tape and Exec Comp Database from 1992 to 1998. If a firm reduces its segment(s) and increases the sales Herfindahl Index by more than 0.1 , it is called a focus-increase firm (FIA). If a firm increases its segment(s) and reduces its Herfindahl Index by more than 0.1, it is called a focus-decrease firm (FDA). A firm that maintains the same segment(s) and has Herfindahl index change of less than 0.1 is said to have no change in focus level.

Size is measured by log (total assets). Leverage is measured by (Total Long Term Debt + Debt in Current Liabilities) / Total Assets. Excess value is computed using the methodology in Berger and Ofek (1995). ROA is measured by Earnings before Interest, Tax, Amortization and Depreciation/Total Assets. Growth is measured by computing the percentage change in sales from year t-1 to t. Herfindahl index is computed using sales multiplier. $H I($ sale $)=\sum_{j=1}^{N}\left(\frac{S A L E_{j}}{\sum_{j=l}^{N} S A L E_{j}}\right)^{2}$ where $j$ denotes the segment in the firm. Tenure is the number of years the CEO has been in place. Percentage pay in options is the ratio of the value of the CEO's option value to the total compensation. CEO total compensation is computed by adding salary, bonus, other annual compensation, total value of restricted stock granted, total value of stock options granted (using Black-Scholes), long-term incentive payouts and all other compensation. CEO equity ownership is the percentage of the company's shares owned by the CEO as reported in the proxy statement. The difference-in-means is measured using t-statistics. The difference-in-medians is tested using the non-parametric Wilcoxon signed-rank test. 


\begin{tabular}{|c|c|c|c|c|c|c|}
\hline & $\mathbf{N}$ & Mean & Median & Std Dev. & Minimum & Maximum \\
\hline \multicolumn{7}{|c|}{ Panel A: Descriptive Statistics for Firms with no Change in Focus: } \\
\hline Size & 2960 & $6.58^{\&}$ & $6.54^{\&}$ & 1.20 & 3.30 & 9.80 \\
\hline Leverage & 3065 & $0.21^{\&}$ & $0.19^{\&}$ & 0.17 & 0 & 0.92 \\
\hline Excess Value & 3078 & $0.15^{\&}$ & $0.13^{\&}$ & 0.51 & -1.37 & 1.38 \\
\hline ROA & 2947 & $0.17^{\& \& \&}$ & $0.16^{\& \& \&}$ & 0.09 & -0.57 & 0.71 \\
\hline Growth & 2587 & 0.17 & $0.11^{\&}$ & 0.33 & -0.66 & 6.46 \\
\hline Herfindahl Index & 3078 & $0.88^{\& \& \&}$ & 1 & 0.22 & 0.19 & 1 \\
\hline Tenure & 3078 & $7.62^{\& \& \&}$ & 5 & 7.70 & 0 & 51 \\
\hline$\%$ pay in options Compensation & 3028 & $29^{\&}$ & $25^{\&}$ & 27 & 0 & 99 \\
\hline Equity Ownership & 1549 & 6.34 & $2.51^{\&}$ & 9.01 & 0.01 & 63.2 \\
\hline Age & 1563 & $56.56^{\&}$ & $57^{\&}$ & 7.98 & 31 & 84 \\
\hline Total Compensation & 3028 & $2385.05^{\&}$ & $1380.49^{\&}$ & 3554 & 3.23 & 63844.8 \\
\hline \multicolumn{7}{|c|}{ Panel B: Descriptive Statistics for FIA Firms: } \\
\hline Size & 124 & $7.26^{\#}$ & $7.33^{\#}$ & 1.21 & 4.95 & 10.05 \\
\hline Leverage & 140 & $0.25^{\#}$ & $0.24^{\#}$ & 0.15 & 0 & 0.69 \\
\hline Excess Value & 140 & $-0.08^{\# \#}$ & $-0.10^{\# \#}$ & 0.44 & -1.18 & 1.27 \\
\hline $\mathrm{ROA}$ & 123 & $0.15^{\# \# \#}$ & $0.15^{\#}$ & 0.06 & -0.02 & 0.32 \\
\hline Growth & 100 & 0.14 & 0.07 & 0.42 & -0.36 & 3.04 \\
\hline Herfindahl Index & 140 & $0.52^{\#}$ & $0.51^{\#}$ & 0.19 & 0.21 & 0.98 \\
\hline Tenure & 140 & 6.74 & 6 & 5.93 & 0 & 29 \\
\hline$\%$ pay in options Compensation & 139 & $31^{\#}$ & $27^{\#}$ & 26 & 0 & 90 \\
\hline Equity Ownership & 53 & 4.98 & $1.2^{\#}$ & 10.39 & 0.01 & 53.4 \\
\hline Age & 65 & $59.14^{\#}$ & $59^{\#}$ & 5.95 & 43 & 77 \\
\hline Total Compensation & 139 & $3156.74^{\#}$ & $2004.01^{\#}$ & 3910 & 331.27 & 28606.57 \\
\hline \multicolumn{7}{|c|}{ Panel C: Descriptive Statistics for FDA Firms: } \\
\hline Size & 198 & $6.90 *$ & $6.87 *$ & 1.07 & 4.32 & 9.20 \\
\hline Leverage & 210 & 0.25 & 0.23 & 0.19 & 0 & 0.90 \\
\hline Excess Value & 210 & $0.07 *$ & $0.04 *$ & 0.52 & -1.22 & 1.36 \\
\hline ROA & 198 & 0.15 & 0.14 & 0.08 & -0.12 & 0.72 \\
\hline Growth & 183 & 0.16 & 0.09 & 0.31 & -0.34 & 0.72 \\
\hline Herfindahl Index & 210 & $0.86^{*}$ & $1 *$ & 0.21 & 0.23 & 1 \\
\hline Tenure & 210 & 7.17 & 5 & 7.25 & 0 & 52 \\
\hline$\%$ pay in options Compensation & 207 & 35 & 31 & 31 & 0 & 99 \\
\hline Equity Ownership & 101 & 5.49 & 1.40 & 9.05 & 0.06 & 47 \\
\hline Age & 135 & 59.47 & 59 & 8.15 & 36 & 85 \\
\hline Total Compensation & 207 & 3563.08 & 2019.95 & 6270 & 131.08 & 62542.32 \\
\hline
\end{tabular}

Difference in mean and median between no focus change firms and FIA firms:

$\#$, \#\# and \#\#\# represent significance at $1 \%, 5 \%$ and $10 \%$ level

Difference in mean and median between no focus change firms and FDA firms:

$\&, \& \&$ and $\& \& \&$ represent significance at $1 \%, 5 \%$ and $10 \%$ level

Difference in mean and median between FIA firms and FDA firms:

$*$, $* *$ and $* * *$ represent significance at $1 \%, 5 \%$ and $10 \%$ level

\section{Acknowledgements}

We appreciate the valuable comments from Stephen Smith, David Nachman, and Omesh Kini. All errors are the sole responsibility of the authors. 


\section{References}

1. Amihud, Y., and B. Lev, 1981, "Risk reduction as a managerial motive for conglomerate mergers", Bell Journal of Economics 12, 605-617.

2. Anderson, R., T. Bates, J. Bizjak, and M. Lemmon, 2000, "Corporate governance and firm diversification", Financial Management 29, 5-22.

3. Berger, P. and E. Ofek, 1995, "Diversification's effect on firm value", Journal of Financial Economics 37, 39-65.

4. Berger, P. and E. Ofek, 1999, "Causes and effects of corporate refocusing programs", Review of Financial Studies 12, 311-345.

5. Berry, T., J. Bizjak, M. Lemmon and L. Naveen, 2000, “CEO turnover and firm diversification”, Working Paper.

6. Billett, M. and D. Mauer, 2003, "Cross subsidies, external financing constraints, and the contribution of the internal capital market to firm value", forthcoming, Review of Financial Studies.

7. Chung, K.H. and S. Pruitt, 1996, "Executive ownership, corporate value, and executive compensation: A unifying framework", Journal of Banking of Finance, 20, 1135-1139.

8. Comment, R. and G. Jarrell, 1995, "Corporate focus and stock returns", Journal of Financial Economics 37, 67-87.

9. Denis, D., D. Denis and A. Sarin 1997, "Agency problems, equity ownership, and corporate diversification", Journal of Finance 52, 135-160.

10. Denis, D. and B. Thothadri, 2000, "Internal capital markets, growth opportunities, and the valuation effects of corporate diversification", Working paper, Purdue University.

11. Hermalin, B. and M. Katz, 2000, "Corporate diversification and agency", Working paper, UC Berkeley.

12. Jensen, M. and W. Meckling, 1977, "Theory of the firm: managerial behavior, agency costs and ownership structure", Journal of Financial Economics 8, 3-80

13. Jensen, M., 1986, “Agency costs of free cash flow, corporate finance and takeovers", American Economic Review 76, 323-329.

14. Julia, L. and T. Opler, 1995, "The causes of corporate refocusing: evidence from the 1980s", Working Paper, UCLA.

15. Lang, L. and R. Stulz, 1994, "Tobin's q, corporate diversification, and firm performance", Journal of Political Economy 102, 1248-1280.

16. Lewellen, W., 1971, "A pure financial rationale for conglomerate merger", Journal of Finance 26, 521537.

17. Lins, C. and H. Servaes, 1999, "International evidence on the value of corporate diversification", Journal of Finance 54, 2215-2239.

18. Mansi, S. and D. Reeb., 2002, "Corporate diversification: what gets discounted?", Journal of Finance 55, 2167-2183

19. Mehran, H. 1995, "Executive compensation structure, ownership and firm performance", Journal of Financial Economics, 38 163-184.

20. Melnic, A. and M. Pollatschek, 1973, "Debt capacity, diversification and conglomerate mergers", Journal of Finance 28, 1263-1273.

21. Rajan, R., H. Servaes and L. Zingales, 2000, "The cost of diversity: The diversification discount and inefficient investment", Journal of Finance 55, 35-80.

22. Rose, N. and A. Shepard, 1997, "Firm diversification and CEO compensation: managerial ability or executive entrenchment", Rand Journal of Economics 28, 489-514.

23. Scharfstein, D. and J. Stein 2000, "The Dark Side of Internal Capital Markets I: Division Rent Seeking and Inefficient Investment", Journal of Finance 55, 2357-2564

24. Shleifer, A. and R. Vishny (1989). "Management Entrenchment: The Case of Manager-Specific Investments", Journal of Financial Economics, 25, 123-140.

25. Stein, J., 1997, "Internal capital markets and the competition for corporate resources", Journal of Finance $52,111-133$. 
Notes 